\title{
STRATEGY OF THE REMOVE AND EASY TBT IN GCC 6 COUNTRIES
}

\author{
Yong-Jae Kim \\ Department of Business Administration, Korea Polytechnic University, \\ Prof. ph.D
}

\begin{abstract}
The last technical barriers to trade(TBT) between countries are Non-Tariff Barriers(NTBs), meaning all trade barriers are possible other than Tariff Barriers. And the most typical examples are (TBT), which refer to measure Technical Regulation, Standards, Procedure for Conformity Assessment, Test \& Certification etc. Therefore, in order to eliminate TBT, WTO has made all membership countries automatically enter into an agreement on TBT. In this study, the elimination strategy of TBT with aid of technical regulations or standards is excluded, and only the conformity assessment shall be considered as the strategic measure of eliminating TBT in GCC(Gulf Cooperation Council) 6 countries. The measure for every membership country to accord with the international standards corresponding to their technical regulations and standards, is only to present TBT related Specific Trade Concern(STC) to WTO. However, each of countries retains its own conformity assessment area, and measures to settle such differences are various as well. Therefore, it is likely required an appropriate level of harmonization in them to carry forward this scheme. KTC(Korea Testing Certification) written MRA with GCC test \& certification company in 2015 years. So Korea exporting company can export to GCC goods with attached test \& certification documents in Korea. To conclude, it is suggest MRA for the remove and reduce TBT to increase export and import among countries.
\end{abstract}

\section{KEYWORDS}

FTA, Standards, Conformity Assessment, TBT(Technical barrier to trade), MRA, WTO

\section{INTRODUCTION}

This paper purpose make to remove and to easy TBT of industrial products such as IT, S/W, IOT, BigData, Home network. Research methodology is review 2nd data analysis and focus group Interview Government officer, Professor and CEO.

This paper compare \& analyze International rule \& system as follow.

First, It is to compare \& analyze the standard, technical regulation, Test \& certification procedure and Inspection. Second, it is review electric/electronic Test, certification and calibration. Third, it is analyze MRA between Korea and GCC 6countries, SDoC, Mutual Acceptance of International certification such as ILAC(APLAC) and IEC CB scheme.

David C. Wyld et al. (Eds) : AIAPP, CRIS, CoSIT, SIGL, SEC - 2018

pp. 47-52, 2018. @ CS \& IT-CSCP 2018

DOI : $10.5121 /$ csit.2018.80404 
This paper intends to draw conclusion and make implication as follows.

First, we must promote FTA and MRA. Second, we make to remove and to easy TBT by MRA between Korea and GCC 6countries. Although the MRA is a system where all parties that have concluded agreement enjoy the advantage, Korea is under a state of concluding only the stage 1 agreements(exchange test documents) with GCC 6 countries. Also, we must conclude MRA stage 2agreements (exchange certification documents)with GCC 6 countries.

\section{PREVIOUS STUdies}

\subsection{STRATEGY TO REMOVE \& EASE TBT IN OECD}

SDoC has strengths in cost reduction, time saving and product information protection aspects compared to the certification system while having vulnerability in terms of product safety issue, etc. Therefore, an effective post market surveillance of the regulation authorities must be supported to be operated effectively. WTO's TBT Committee has suggested that the SDoC is more effective TBT elimination method than the MRA (OECD, 2000).

\subsection{STRATEGY TO REMOVE \& EASE TBT IN APEC TEL MRA}

Testing and certification are expensive procedures for exporters, importers and regulators that increase the cost to users and delays the availability of products in a large number of markets.

All stakeholders benefit from simplified procedures that can reduce these costs. At the same time, regulators need to have confidence in the quality of testing that provides the basis for certification of equipment.

In June 1998, the APEC1 Telecommunications and Information Ministers agreed to streamline APEC-wide processes for the testing and type-approval of telecommunications equipment.

This landmark arrangement, the Mutual Recognition Arrangement for Conformity Assessment of Telecommunications Equipment (APEC TEL MRA2), was the first multilateral agreement of its type in the world.

This Arrangement streamlines the Conformity Assessment Procedures for a wide range of telecommunications and telecommunications-related equipment and facilitates trade among the APEC member economies.

It reduces a significant barrier to what is projected to be a US\$60 billion industry by 2010 .Its scope includes all equipment subject to telecommunication regulations, including wire line and wireless, terrestrial and satellite equipment. For such equipment, the MRA covers electromagnetic compatibility (EMC), specific absorption rate (SAR) and electrical safety aspects as well as purely telecommunications aspects of the conformity assessment requirements.

\section{STRATEGY TO REMOVE/EASE OF THE TBT}

TBT is an abbreviation for ' Technical Barriers to Trade' while this stands for the various obstacles in terms of trade that hinder the free movement of goods and services as the trading 
partner countries adopt and apply different Technical Regulations, Standards, Test \&Certification Procedures and Inspection Systems, etc.

\subsection{STRATEGY TO REMOVE/EASE OF THE TBT}

TBT makes the countries to harmonize technical regulations, standards or conformity assessments with the international standards and does not occur in case of being transparent. However, the fact is that TBT occurs if a specific country does not comply with the principles above during legislation and amendment of the laws related to technical regulations, standards or conformity assessments while STC must be submitted to settle this TBT. In the conformity assessment of ICT section, various methods of solution exist on TBT depending on the issue other than filing a lawsuit to WTO if a specific country operates the conformity assessment section differently from TBT.

\section{(1) Request for Introduction of SDoC System}

SDoC system stands for the one to guarantee market autonomy and raise efficiency of restriction as a system for the supplier to guarantee by evaluating whether its own product is appropriate for the concerned standard by escaping from the compulsory certification system which requires certification in relation to the product manufacture. Since SDoC(Supplier's Declaration of Conformity) is a follow-up and legal system, it is the method of releasing new products under the manufacturer's own responsibility to become responsible for various problems to follow.

\section{(2) Strategy of MRA}

The manufacturers of industrial products are able to export only after acquiring a compulsory standard certification mark. While MRA is concluded in order to save cost and time required for this, only the test report implemented at the exporting country is recognized if MRA stage 1(exchange test documents) is concluded while both the test report and the certification market may be implemented at the exporting country may be implemented if MRA stage 2(exchange certification documents) is concluded.

If both countries conclude the MRA such as FTA, it would be opening the homeland market to the manufacturer of partner country since it is customs-free.

\subsection{DOMESTIC ELECTRIC \& ELECTRONIC CERTIFICATION SYSTEM AND RELATED LAWS}

\section{- Conformity Assessment System of Korea}

Supplier's Declaration of Conformity (SDoC) the one to guarantee market autonomy and raise efficiency of restriction as a system for the supplier to guarantee by evaluating whether its own product is appropriate for the concerned standard by escaping from the conventional compulsory certification system which requires certification in relation to the product manufacture. 


\section{(1) Acceptance of Internationally Certified Test Report}

In addition to the method of concluding an MRA, various methods to recognized the test reports estimated at the partner country or a third country exist. Among them, the most widely used method is the one to accept test reports of the testing agencies that have been recognized by ILAC(APLAC) and CB Scheme. Test \& Certification Based Infrastructure Setup Support

\subsection{COMPARATIVE ANALYSIS AND STRATEGY OF REMOVE AND EASE TBT}

The systems mentioned above have different characteristics from each other. If the comparative analysis is performed from the perspectives of scope of effect, intensity of effect and usage status in Korea, they can be summarized as follows.

[Figure 1] Comparative Analysis and strategy of the remove and ease TBT

\begin{tabular}{|c|c|c|c|c|c|}
\hline & \multirow[t]{2}{*}{ MRA } & \multirow[t]{2}{*}{ SDoC } & \multicolumn{2}{|c|}{$\begin{array}{c}\text { Mutual Acceptance of International } \\
\text { Certification }\end{array}$} & \multirow{2}{*}{$\begin{array}{c}\text { Infrastructure } \\
\text { Setup Support } \\
\text { Project }\end{array}$} \\
\hline & & & ILAC(APLAC) & CB Scheme & \\
\hline $\begin{array}{l}\text { Scope of } \\
\text { Effect }\end{array}$ & $\begin{array}{c}\text { Partner } \\
\text { country of } \\
\text { agreement }\end{array}$ & All countries & $\begin{array}{l}\text { Participating } \\
\text { countries }\end{array}$ & $\begin{array}{l}\text { Participating } \\
\text { countries }\end{array}$ & $\begin{array}{l}\text { Beneficiary } \\
\text { countries }\end{array}$ \\
\hline $\begin{array}{l}\text { Intensity of } \\
\text { Effect }\end{array}$ & In stages & $\begin{array}{l}\text { Limited to } \\
\text { the products } \\
\text { that have } \\
\text { applied the } \\
\text { system }\end{array}$ & $\begin{array}{l}\text { By accepted } \\
\text { field }\end{array}$ & By accepted field & $\begin{array}{c}\text { Different } \\
\text { according to the } \\
\text { supported } \\
\text { standard }\end{array}$ \\
\hline $\begin{array}{l}\text { Current } \\
\text { Status of } \\
\text { Usage In } \\
\text { Korea }\end{array}$ & $\begin{array}{l}\text { Completed } \\
\text { stage } 1 \\
\text { conclusion } \\
\text { with } 5 \\
\text { countries } \\
\text { and } \\
\text { negotiating } \\
\text { with a } \\
\text { number of } \\
\text { countries }\end{array}$ & $\begin{array}{l}\text { Applied to } \\
\text { the products } \\
\text { with low } \\
\text { level of } \\
\text { harm }\end{array}$ & $\begin{array}{l}\text { Field of private } \\
\text { sector standards }\end{array}$ & $\begin{array}{l}\text { EMC field is not } \\
\text { used }\end{array}$ & Under support \\
\hline Remarks & $\begin{array}{l}\text { Need to } \\
\text { promote } \\
\text { upper stage } \\
\text { with more } \\
\text { countries }\end{array}$ & $\begin{array}{l}\text { Necessity to } \\
\text { extend } \\
\text { applied } \\
\text { products is } \\
\text { low in a } \\
\text { short run }\end{array}$ & $\begin{array}{l}\text { Handle flexibly } \\
\text { depending on the } \\
\text { acceptance } \\
\text { situation of } \\
\text { foreign countries }\end{array}$ & $\begin{array}{l}\text { Handle flexibly } \\
\text { depending on the } \\
\text { acceptance } \\
\text { situation of foreign } \\
\text { countries }\end{array}$ & $\begin{array}{l}\text { Need to extend } \\
\text { support }\end{array}$ \\
\hline
\end{tabular}

If both countries conclude the MRA such as FTA, it would be opening the homeland market to the manufacturer of partner country since it is customs-free. 
Among APEC members, time and cost required for preparing the copy of agreement can be saved if the MRA Guide prepared by this organization is used. Although Korea has concluded MRA stage 1 with the United States, Canada, Chile and Vietnam, etc., the effect is clearly shown only in the MRA with the United States.

\section{CONCLUSION}

This study intends to draw conclusions and make policy implications as follows.

First, we must promote a multi-track simultaneous agreements with the countries that have necessity of short-term promotion.

Second, the countries with necessity of short-term promotion on the preferential basis are China, Japan and USA, etc.

Third, it is necessary to conclude MRA agreement with the leading countries among the GCC 6 countries on the preferential basis. It is necessary to prepare negotiation on the preferential basis with GCC 6 countries.

Fourth, support on the countries that have not fully prepared the conformity assessment system needs to be gradually extended. However, the method of support on these countries also must vary depending on the country. KTC (Korea Testing Certification) written MRA GCC test \& certification company in 2015 years. So Korea exporting company can export to GCC goods with attached test \& certification documents in Korea. To conclude, it is suggest MRA for the remove and reduce TBT to increase export and import among countries.

\section{REFERENCES}

[1] Beghin and Bureau (2001). "Quantification of Sanitary, Phytosanitary, and Technical Barriers to Trade forTrade policyAnalysis",Working Paper, Center for Agricultural and Rural Development, Iowa State University. pp102-119

[2] Johnson, C. (2008). Technical Barriers to Trade: Reducing the Impact of Conformity Assessment Measures.USITC Working Paper.19.pp34-37[1]

[3] OECD (1999). An Assessment Of The Costs For International Trade In Meeting Regulatory Requirements pp66-76

[4] OECD (2000). An Assessment Of The Costs For International Trade In Meeting Regulatory Requirements(TD/TC/WP(99)8/FINAL).pp27-31

[5] OECD (2013), Annual Report on the OECD Guidelines for Multinational Enterprises (2013), OECD publishing pp166-177

[6] OECD(2011), OECD Guidelines for Multinational Enterprises 2011 Edition, OECD publishing.pp127-136

[7] P. S. Huh, Y. J. Park and K. S. Lim. Grouping and Priority Setting for the Expected IT Equipment MRA Conclusion Countries through Index Analysis. (2007)「International Regional Research $\rfloor$. 11(1): pp541-561. 
[8] UN Global Compact(2014), United Nations Global Compact Strategy 2014, UN Global Compact. pp76-89

[9] Y.J. Chang and J.M. Seo The Impact of Technical Barriers to Trade (TBT) on Bilateral Trade: A Case of Korea.(2014) 「InternationalTrade Research」 . 19(1): pp10-33.

[10] Y.K. Lee. Empirical Analysis on the Economic Effect of Mutual Recognition Agreement (MRA) among CountriesIn the Data Communication Sector: Focused on the Case of Korea-U.S. Areement. (2014)「National Policy Research28(3):pp1-26.

\section{AUTHORS}

ISO TC 68 Member

ISO TC 195 Member

ISO/IEC SC32 WG1 Vice convenor

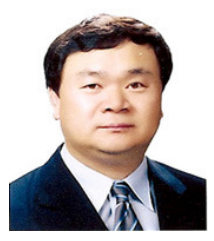

